\title{
1 Study of a small scale tyre-reinforced embankment
}

2

3 Authors:

4 Lihua Li ${ }^{\text {a,b }}$, Henglin Xiao ${ }^{\text {a }}$, Pedro Ferreira ${ }^{\mathbf{b}}$, Xilin Cui ${ }^{\mathbf{a}}$

$5{ }^{a}$ School of Civil Engineering and Architecture, Hubei University of Technology,

6 Wuhan, 430068, China

$7 \quad{ }^{\mathrm{b}}$ Corresponding author: Pedro Ferreira

8 Department of Civil, Environmental and Geomatic Engineering - University College

9 London - UCL

10 Gower Street, WC1E 6BT, London, UK

11 Phone: +44 (0) 207679 4366, FAX: +44 (0) 2073800986

12 e-mail: p.ferreira@ucl.ac.uk 


\section{ASTRACT}

2 Tyre-reinforced soil, used to improve slope stability, retaining walls, etc., has an

3 excellent mechanical performance, and has the capability of a wider application and of

4 reducing waste disposal costs. This article studies the stress and deformation

5 characteristics, as well as the influencing factors related to the reinforcing arrangement,

6 through small scale model embankment tests. It is shown that tyre reinforcement highly

7 improved the strength of the model embankments; much higher stresses were mobilised

8 inside the soil mass (around 2 times higher in comparison with the unreinforced

9 embankment). There is an obvious plastic flow in the unreinforced embankment, while

10 the plastic zone, on the reinforced embankments, was difficult to determine.

11 Comparisons between the vertical settlement of the embankments show that the

12 settlement of the reinforced embankment is roughly half of the settlement of the

13 unreinforced embankment, for the same vertical load applied. These results also show

14 that the tests with the top layer of reinforcement nearer the load application area and a

15 smaller distance between the intermediate layers have a better performance, particularly

16 in dense fabrics. The location of the top reinforcement layer seems to dominate the

17 failure modes of the reinforced and unreinforced embankments, the horizontal deformations and the location of the shear bands in the embankment.

\section{Keywords}

21 Geosynthetics, Waste tyres, soil reinforcement, stress, settlement, model test 


\section{1. Introduction}

The number of waste tyres around the world has been increasing rapidly in recent years and has become an urgent and serious environmental and economic problem (Wiem et al.2005; Long et al. 1996; Bosscher et al. 1997). Waste tyres can be used as reinforcement in the field of geotechnical engineering, and have been regarded as an ideal option (Donald et al., 2008; Huat et al., 2008) to strengthen slopes, retaining walls, embankments, foundations, abutments and, more recently, docks. Waste tyres are normally tied together to either form discrete reinforcement layers within the soil or to provide better stability to the façade of retaining structures. They can also be shredded, mixed into the soil mass and compacted, forming a uniformly reinforced layer; this application, however, requires extra energy and it is less environmentally friendly than using unprocessed waste tyres.

A structure reinforced by tyres usually has the advantages of better seismic performance and durability, low cost, and, although more labour intensive, a simpler construction process. Therefore, it is believed that tyre-reinforced soil will have a wider application in the future, particularly in countries where labour costs are low and mechanisation is not widespread.

The first application of tyre-reinforced soil can be traced back to 1984 , where a $5 \mathrm{~m}$ high 10m long retaining wall, was reinforced in France. In the 1990's, another retaining wall, $4 \mathrm{~m}$ high and $60 \mathrm{~m}$ long, in Brazil, was also reinforced using tyres (Sayão et al., 2009). The results of the tests performed on both structures have confirmed the 
1 suitability of tyres to be used as reinforcement in slopes or retaining walls. Other

2 applications have been trialled in many other countries, mainly in slope reinforcement 3 and retaining walls (Garga et al., 2007).

4 The literature on tyre reinforcement has shown that the ultimate pull-out capacity of

5 a waste tyre is 1.25 times that of a geocell or similar reinforcing material (Keun et al.

6 2011, Dade Zhang et al. 2011). In addition, the effect of reinforcement has also been

7 found to be significant when applied to a sand foundation (Yoon et al., 2004, 2008). In

8 spite of the current use of tyres as reinforcement, there is insufficient understanding of

9 the mechanism of waste tyres in a reinforced soil, which restricts further applications.

10 Therefore, tests on a small scale model embankment, presented in this article, were

11 carried out to investigate the mechanical performance of a tyre-reinforced sand

12 embankment, including stress-strain characteristics and failure mode. In this study, the

13 effects of soil density and reinforcing arrangement were also considered.

\section{Materials, Methodology, Instrumentation and Test Procedure}

Tyre reinforced model embankments with a slope ratio of 1:1.3 and a final height of

$17 \quad 0.65 \mathrm{~m}$ were prepared and tested, in an effort to study the stress and deformation characteristics of different combinations of initial density and reinforcement

19 arrangement. For the embankment, a medium size quartzitic sand was used as the

20 filling material, with a D50 of $0.28 \mathrm{~mm}$ and a $\mathrm{Cu}$ of 5.3 . 
All the model embankments were reinforced with small waste tyres from

2 electromobile vehicles having a diameter of $25.4 \mathrm{~cm}$ and a height of $9 \mathrm{~cm}$. Each

3 embankment was built using 3 layers of tyre reinforcement, where the tyres on each

4 layer were tied together using a metal wire. In total 10 model embankments were

5 created using 2 different relative densities and combinations between the distance from

6 the top tyre layer and the upper embankment surface, (a), and the vertical distance

7 between adjacent tyre layers, (b). Figure 1 shows a sketch of the embankment, while

8 Table 1 indicates the initial configuration of each embankment tested.

9 All model embankments were prepared within a purposely designed steel box of $102000 \times 800 \times 760 \mathrm{~mm}$, with one $12 \mathrm{~mm}$ armour-plated side glass panel. To create the 11 embankments, the sand was compacted in $100 \mathrm{~mm}$ layers, using a constant weight 12 hammer, dropping from a constant height. The required relative density was achieved 13 by controlling the energy applied to each layer, until the reinforcement level was 14 reached. The necessary number of tyres for each reinforcement layer were put in place 15 and tied together, with more sand being compacted in between the reinforcement. This 16 procedure was followed until the final height of the embankment was achieved.

17 To measure the embankment deformation, face markers were installed on the slope surface behind the glass panel, these were monitored using photogrammetry. A set of 19 pressure cells were installed, inside of the embankment, to measure vertical stresses in 20 between soil layers (cells number T1, T3, T4, T7 and T8), and inside the tyre layers 21 (cells number T2, T5, T6, T9 and T10). Figure 1 shows the arrangement of the 
1 instrumentation in the embankment, it is important to point out that not all pressure

2 cells were installed at a given test.

3 An $800 \mathrm{~mm}$ long, $400 \mathrm{~mm}$ wide and $40 \mathrm{~mm}$ thick loading plate with a hydraulic jack

4 was used to load the top surface of the embankment in increments of $0.5 \mathrm{MPa}$ of

5 hydraulic pressure, followed by a resting period at constant load of 5 minutes, during

6 which all sensors were logged. A test would be ended when either of the following

7 conditions was observed: (1) a shear surface (crack) appeared along the slope surface,

8 together with a sharp increase of the lateral displacement, or (2) a sudden increase on

9 the vertical settlement occurred, together with a sudden reduction on the vertical 10 applied load.

\section{Test results}

\subsection{Effect of tyre reinforcement on stress}

All the reinforced embankment tests performed showed similar behaviour and test

15 A3 was selected as representative, therefore Figure 2 only shows the variation of 16 pressure, measured by the pressure cells located underneath the loading application 17 area, on tests A3 (reinforced) and A5 (unreinforced). The vertical stress, measured on 18 the unreinforced embankment A5 (Figure 2b), show an abrupt reduction in all 19 monitored points after failure. As expected, the highest vertical pressure measured is 20 located on pressure cell $\mathrm{T} 2$, with the other pressure cells measuring lower vertical stresses; generally the deeper the pressure cell, the lower the vertical stress measured,

22 this was also true for the B tests. 
A comparison between the stresses measured on pressure cell $\mathrm{T} 2$ and $\mathrm{T} 4$, in all A

2 tests (Figure 3), has shown that the depth of the first reinforcement layer does seem to

3 affect the stresses measured, however, the reinforcement layer allows the soil to reach

4 stresses that are slightly higher than the stresses reached by the unreinforced

5 embankment, for the same loading stage. Furthermore, the extra lateral strength, given

6 by the reinforcement layers, allows the soil to reach vertical stresses that are 2 times

7 higher than the maximum stresses achieved by the unreinforced embankment. Pressure

8 cell T4, located below the first reinforcement layer show similar pressure values to

9 tests A1 and A2 and these are lower than the stresses mobilised by the unreinforced

10 embankment, for the same pressure stage (Figure 3). Similar results can be observed

11 on tests A3 and A4 (Figure 3b). The results suggest that the reinforcement layers have

12 a great impact on the transmission of stresses in the embankment, showing how

13 effective a reinforcement layer is in confining the unreinforced layers above, allowing

14 a much greater vertical stress to develop within the top layers and reducing the vertical

15 stresses transmitted to the layers below.

\section{$17 \quad 3.2$ Effect of tyre reinforcement on settlement}

18 During the test procedure, settlements were measured immediately under the central

19 axis and at the slope surface, these were plotted against the hydraulic vertical pressure

20 applied and are shown on Figures 4 and 5. The results show that the reinforcement

21 plays an important role in reducing the amount of vertical settlement in all test 
1 conditions; the settlement measured on the reinforced embankments is roughly half of

2 the settlement of the unreinforced embankment. Also, the settlement values measured

3 on the dense model embankments (Figure 5) are lower than the settlements measured

4 on the loose model embankments (Figure 4), by as much as a factor of 2 . The model

5 embankments with a loose fabric (B tests), show very similar load-settlement profiles

6 in the central axis (Figure 4a), indicating that the distribution of the reinforced layers,

7 inside the soil mass, does not affect, significantly, the load-settlement curves measured

8 at the centre line of the embankment. This difference, however, is not seen on the

9 measurements made at the slope surface, embankments with the less dense fabric seem

10 to reach a maximum vertical settlement (Figure $4 b$ ) and not much change is seen until

11 failure occurs. The denser fabric embankments, however, deform linearly until failure

12 occurs, at similar values of surface vertical settlement (Figure $5 b$ ).

13 It is worth mentioning that when comparing Figures $4 \mathrm{a}$ and $5 \mathrm{a}$, it is clear that the

14 reinforcement improves the performance of the embankment. It is also clear that the

15 effects of the reinforcement arrangement are much better seen on the denser

16 embankments. Tests A1 and A3 have the first reinforcement layer at a depth of $250 \mathrm{~mm}$

17 from the top and show a stiffer response to loading than tests A2 and A4, which have the first reinforcement layer at 300mm depth. The difference in thickness between the

19 two layers is small, however it is enough to indicate that, in dense embankments, it

20 may be beneficial to have the first layer of reinforcement installed at a shallower depth,

21 where the change in vertical stress is higher and the confinement provided by the 
1 reinforcement more effective.

33.3 Effect of tyre reinforcing arrangement

4 In order to understand the effects of the reinforcement, the load-settlement curves of

5 the reinforced embankments were re-plotted on Figures 6 and 7. Figure 6 shows a

6 comparison between the tests with the same distance between reinforcement layers, $b$,

7 as shown in Figure 1. The results show that, for the dense samples $(\mathrm{Dr}=45 \%)$,

8 embankments A1 (Figure 6a) and A3 (Figure 6b), behave in a stiffer manner, due to

9 having the smallest distance between the loading plate and the top reinforcing layer.

10 Tests B1 and B3, also in the same figure, appear to show a similar effect, however,

11 because of the lowest relative density, this effect is not as dominant as in the denser

12 samples tested.

13 Figure 7 compares model embankment tests with the same distance between the load 14 plate and the first reinforcing layer, a (Figure 1). In the figure, it is clear that tests A1 15 (Figure 7a) and A2 (Figure 7b) have a stiffer response, indicating that a short distance 16 between layers will stiffen the response of the model. The same behaviour can be seen 17 for the loose model embankments B1 and B2, although in this case, again, the density is probably the dominant factor, not allowing the differences between reinforcement 19 arrangements to be clearly seen.

20 The results show that, the first layer of reinforcement seems to be the most 21 significant in reducing the settlement and should be positioned near the load 
1 application point. The distance between reinforcement layers also affects the settlement

2 and the results show that the smaller this distance, the lower is the settlement. This

3 indicates that the reinforcement is effective in creating a confinement between layers,

4 better distributing the stresses along the embankment, therefore, the closer the

5 reinforcement layers are to the load application point, the more effective is the

6 reduction in settlement.

7 Another important factor is the density of the reinforced soil: the higher the density,

8 the higher is the improvement seen by the reinforcement arrangement in the test

9 embankment. As expected, the settlement of the reinforced embankment with the

10 higher density was found to be considerably smaller than that with the lower density

11 with the differences in settlement becoming more significant as the load increases.

\subsection{Effect of reinforcement on embankment failure}

14 The failure mode of the embankments were found to be distinct during the tests. The 15 displacements, at different locations, on the sloping surface, were measured and plotted 16 against the depth of the embankment for 3 different vertical pressures (Figures 8 to 10).

17 It is important to point out that the unreinforced embankment was not capable of 18 resisting more than $3 \mathrm{MPa}$, therefore the horizontal displacements plotted are used as 19 comparisons; the pressure applied on the unreinforced embankment is indicated in the 20 legend. At the end of the tests, pictures were taken from each embankment, where a line 21 was used to mark the limit of the area with high deformation, (Figure 11). 

embankment is much higher than the deformations of the reinforced embankments, for

3 every depth. It is also clear that horizontal deformations of the unreinforced 4 embankment extend almost to the toe of the slope, whilst in the reinforced 5 embankments, most of the deformation is concentrated at the upper part and it seems to 6 be influenced by the reinforcing arrangement. Moreover, there is an obvious plastic 7 flow in the unreinforced embankment, while the plastic zone, on the reinforced 8 embankments, was difficult to determine. This can also be seen in Figure 11, where the 9 unreinforced embankment is shown to mobilise a much bigger soil mass than the 10 reinforced embankments. The depth at which the maximum horizontal displacement 11 occurs seems to be in accordance with that of the location of the first tyre reinforcement 12 layer. Tests A2 and A4, have the first layer of reinforcement at 250mm from the top and 13 the location of the highest horizontal deformation is between 300 and $400 \mathrm{~mm}$ below the 14 top surface, while tests A1 and A3, that have the first layer of reinforcement at $250 \mathrm{~mm}$ 15 below the top, have mobilised the highest horizontal displacements between 400 and $16500 \mathrm{~mm}$ below the top surface, indicating a failure between the second and third layers 17 of reinforcement. This is consistent with the measurements of stresses previously mentioned as the reinforcement contributes to improving the overall stiffness of the system and reducing the development of deformations.

\section{Discussion}


It is clear that reinforcement improves, significantly, the performance of a soil

2 embankment and, in this particular case, if waste materials can be used as reinforcement,

3 the economic and environmental benefits are even higher. This work have shown that

4 there is the possibility of further improvement in the performance of the reinforcement,

5 by making sure that the spacing between reinforcement layers are organised in a

6 coherent manner. There are many questions to be answered in this respect and more

7 research will need to be performed, especially large scale tests and measurements on

8 real embankments; these are likely to have wider spacing between reinforcement layers

9 and mobilise larger stresses that could lead to the failure of the reinforcement. Where

10 the availability of waste tyres is not a concern, a denser arrangement is possible, making

11 better use of the available strength.

12 The authors have tried to scale up their results, however, scaling the results up also 13 means that the thickness of the reinforcement layers and the size of the soil particles 14 must also be scaled, therefore this was not performed. Also, the authors understand that 15 the load application plate used will develop friction with the sand particles and it is 16 likely that the load plate should be considered a rigid reinforcement layer. Another issue 17 is the use of a granular material, however in small scale tests it is easier to work with granular materials than cohesive ones, especially since total stresses are equal to

19 effective stresses. Nevertheless the authors would expect to find similar behaviour in a 20 drained case, be it saturated or not, especially in the civil engineering range of stresses. 


\section{5. Conclusions}

2 Waste tyres are a big environmental problem that will only increase with time. One of

3 the solutions is to use it as a low cost embankment reinforcement material, with the

4 advantage of reducing waste disposal costs. The following conclusions can be drawn

5 from this study:

6 (a) The tyre reinforcement significantly improved the strength of the model

7 embankments, the results show that stresses 2 times higher were mobilised inside the

8 soils mass.

9 (b) At failure, the reinforcement kept the vertical stresses roughly constant, not allowing

10 an abrupt reduction or a brittle failure as observed in the unreinforced embankments.

11 (c) With the presence of reinforcement, the slope settlements were reduced to halve,

12 with the best reinforcement configuration found when the first layer is near the surface

13 and the space between layers is small. The results also show that denser fabrics not only

14 have lower settlements but make better use of the reinforcement properties.

15 (d) The horizontal deformation of the unreinforced embankment is much higher than the

16 reinforced embankments and it extends almost to the toe of the slope, while in the

17 reinforced embankments, most of the deformation is concentrated on the upper part,

18 above the final reinforcing layer.

19 (e) The failure modes of the reinforced and unreinforced embankments are quite

20 different. The unreinforced embankments have a general shear failure, while the failure

21 region reduces in size with the introduction of reinforcement, as well as the reinforcing 
arrangement.

\section{Acknowledgements}

4 The authors would like to extend their gratitude to the National Natural Science

5 Foundation of China (No.51308197), who funded this research, as well as the graduate 6 students Miaojun Sun and Long Sun for their hard work in carrying out the testing.

\section{References}

9 Bosscher, Peter; Tuncer, B.Edil and Kuraoka, Senro (1997). Design of highway embankments using tyre chips. Journal of Geotechnical and Geoenvironmental Engineering. 123 (4):295-304.

Donald C. Slack; Garcia, Guillermo ; Roth, Robert; Hoenig, Stuart ; Segovia, Rafael ; Soto, Refugio; Frayre,Arturo. 2008. Engineered conservation structures using discarded tyres. American Society of Agricultural and Biological Engineers Conference on 21st Century Watershed Technology: Improving Water Quality and Environment. 163-170.

Sayão, A.S.F.J.; Gerscovich, D.M.S.; Medeiros, L.V. ; Sieira, A.C.C.F. 2009. Scrap tire-an attractive material for gravity retaining walls and soil reinforcement. Journal of Solid Waste Technology and Management. 35(3), 135-155.

Garga, V.K.; O’Shaughnessy, V. 2007. Reinforced earthfill. Part 1: Construction of a test fill performance, and retaining wall design. Canadian Geotechnical Journal. 37, 75-96.

Keun Soo Kim, Yeo Won Yoon, Gil Lim Yoon. 2011. Pullout behavior of cell-type tyres in reinforced soil structures. Journal of Civil Engineering .15(7), 1209-1217. 
1 Huat, Bujang B.K. ; Aziz, Azlan A.; Chuan, Loh Wooi. 2008. Application of scrap tyres as earth reinforcement for repair of tropical residual soil slope. Electronic Journal of Geotechnical Engineering . 13, 1-9

Yoon, Yeo Won; Seung Beom Heob; Keun Soo Kim. 2008. Geotechnical performance of waste tyres for soil reinforcement from chamber tests. Geotextiles and Geomembranes. 26, 100-107.

Yoon Yeo Won, Sung Han Cheonb, Dae Seong Kang. 2004. Bearing capacity and settlement of tyre-reinforced sands. Geotextiles and Geomembranes. 22, 439-453.

Yoon, Yeo Won . 2008. Engineering characteristics of tyre treads for soil reinforcement. Proceedings of the International Workshop on Scrap Tyre Derived Geomaterials Opportunities and Challenges.83-105.

Wiem Ben Hassine, Hedi Hassis, Abdelwahed Ben Hamida. 2005. An extension, flexural, and warping model of soil reinforced by used tyre's portions related by linear inclusion. European Journal of Mechanics A/Solids, 24, 630-643.

Long, N.T. 1996. Utilization of used tyres in civil engineering - the pneusol'tyresoil'. Proceedings of 2nd International Congress on Environmental Geotechnic. Osaka, Japan, 809-814. 


\section{$1 \quad$ Figure Captions}

2 Figure1- Elevation profile with the details of the reinforcement layouts tested and the 3 location of the instrumentation.

4 Figure 2- Reinforced and unreinforced variation of the vertical stress with depth: a) Test A3 and b) Test A5.

6 Figure 3- Pressure cell measurement, readings on T2 and T4 for: a) tests A1, A2 and A5 and b) tests A3, A4 and A5

8 Figure 4- Settlement-loading curves of the sand embankment with relative density $=$ $32 \%$ : a) near the central axis and b) near the slope surface

10 Figure 5- Settlement-loading curves of the sand embankment with relative density = 45\%: a) near the central axis and b) near the slope surface

Figure 6- Comparison between tests with the same distance separating the tyre

Figure 10- Horizontal displacement measured on Tests A before failure. Pressure applied on the loading system indicated on each test. 
1 Figure 11- Failure mode (the line shows the location of the lowest shear surface on the 2 slope face): a) Test A5; b) Test A1; c) Test A2; d) Test A3 and e) Test A4. 
Table 1

Different variables adopted in the model test

\begin{tabular}{|c|c|c|c|}
\hline $\begin{array}{c}\text { Relative } \\
\text { Density }(\%)\end{array}$ & $\begin{array}{l}\text { Vertical distance } \\
\text { (b) between the } \\
\text { centres of the } \\
\text { tyre layers }(\mathrm{mm})\end{array}$ & $\begin{array}{l}\text { Vertical distance }(\mathbf{a}) \\
\text { between the top tyre layer } \\
\text { and the embankment } \\
\text { surface }(\mathrm{mm})\end{array}$ & Test Name \\
\hline \multirow{5}{*}{45} & \multirow{2}{*}{100} & 250 & $\mathrm{~A} 1$ \\
\hline & & 300 & $\mathrm{~A} 2$ \\
\hline & \multirow{2}{*}{150} & 250 & A3 \\
\hline & & 300 & A4 \\
\hline & \multicolumn{2}{|c|}{ Without reinforcement } & A5 \\
\hline \multirow{5}{*}{32} & \multirow{2}{*}{100} & 250 & B1 \\
\hline & & 300 & B2 \\
\hline & \multirow{2}{*}{150} & 250 & B3 \\
\hline & & 300 & B4 \\
\hline & \multicolumn{2}{|c|}{ Without reinforcement } & B5 \\
\hline
\end{tabular}


- Pressure Cells

- Photogrametry targets

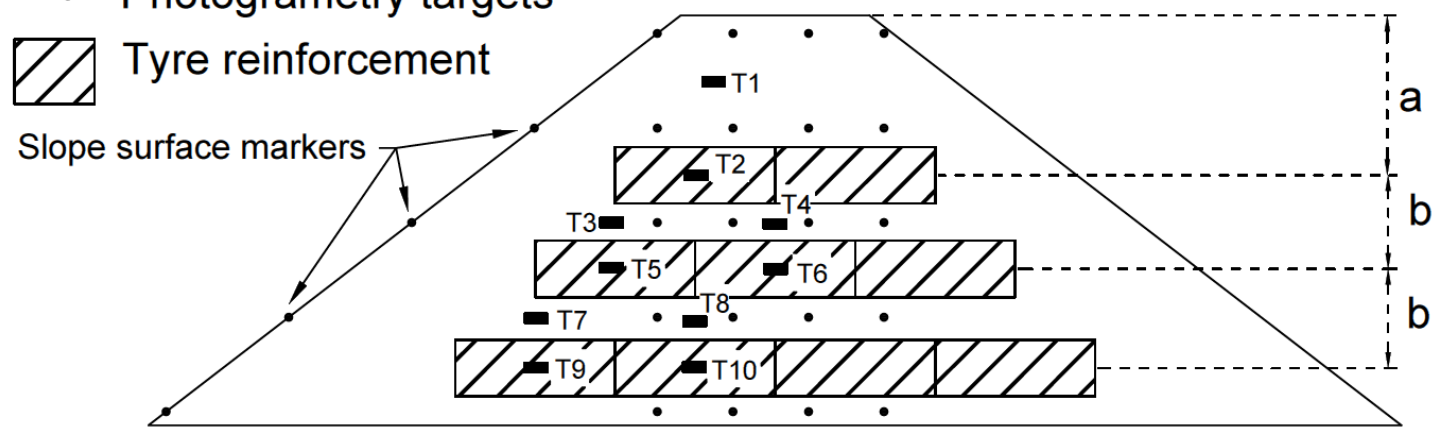

Figure 1- Elevation profile with the details of the reinforcement layouts tested and the location of the instrumentation. 


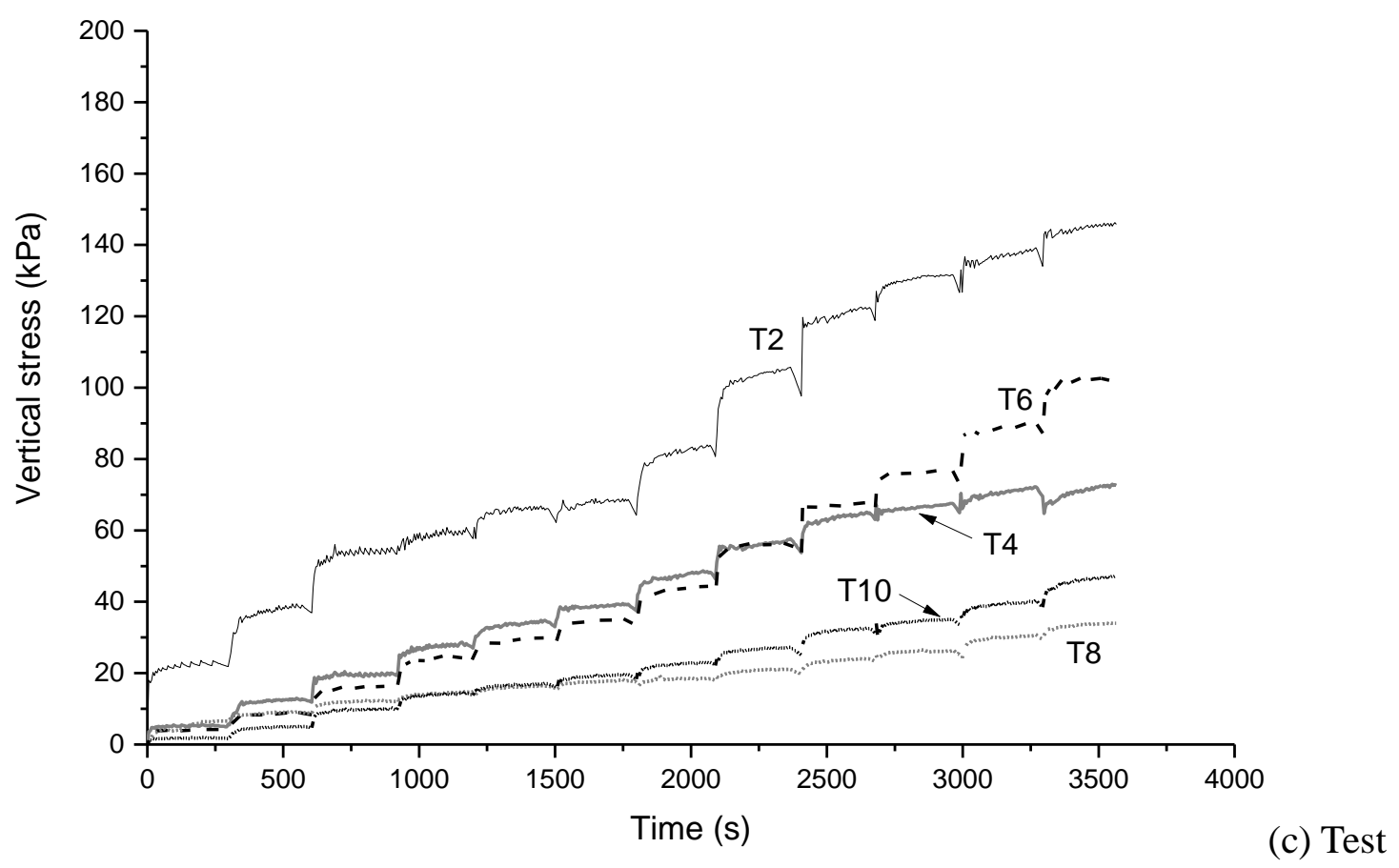

(a) Test A3

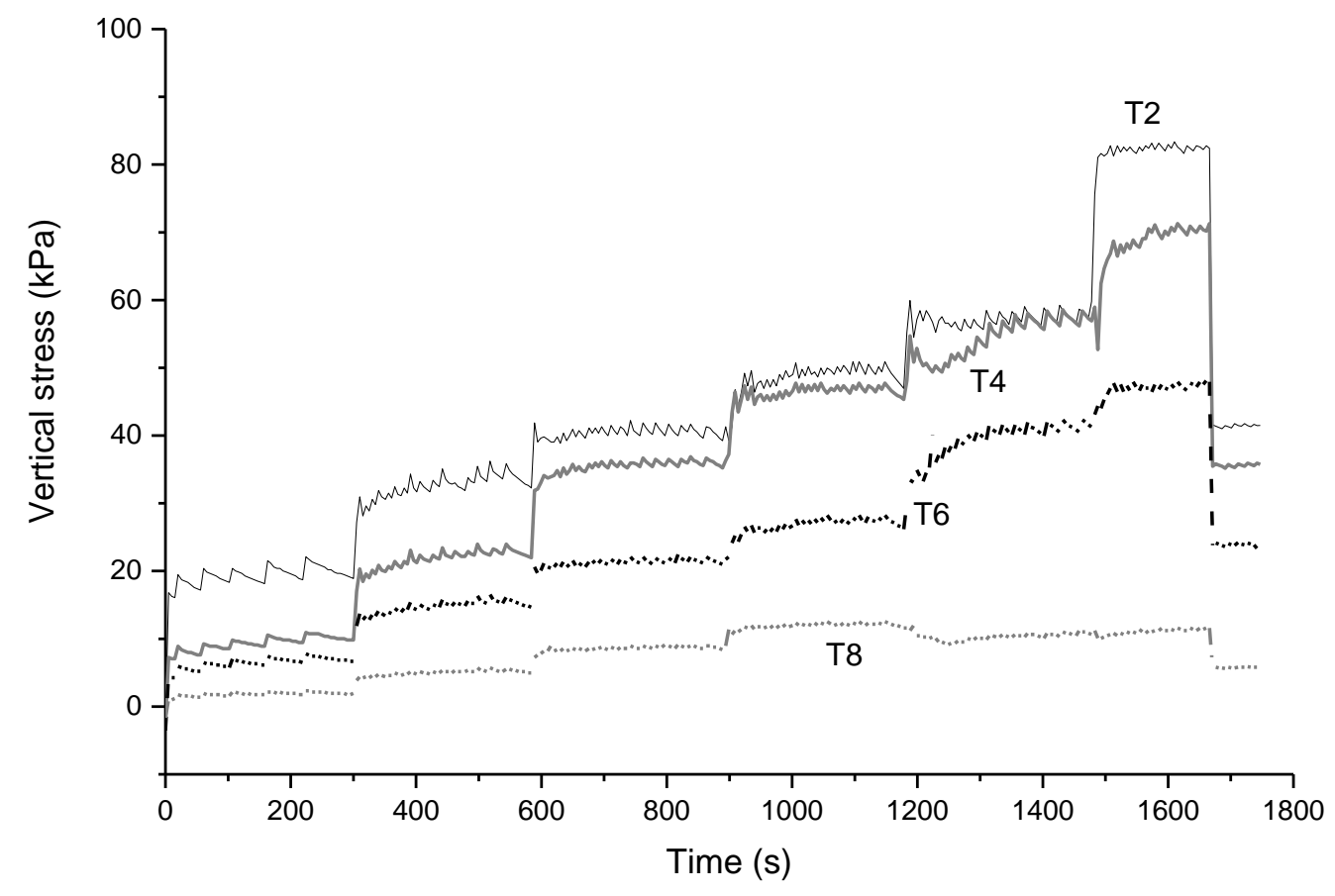

(b) Test A5

Figure 2- Reinforced and unreinforced variation of the vertical stress with depth: a)

Test A3, b) Test A5. 


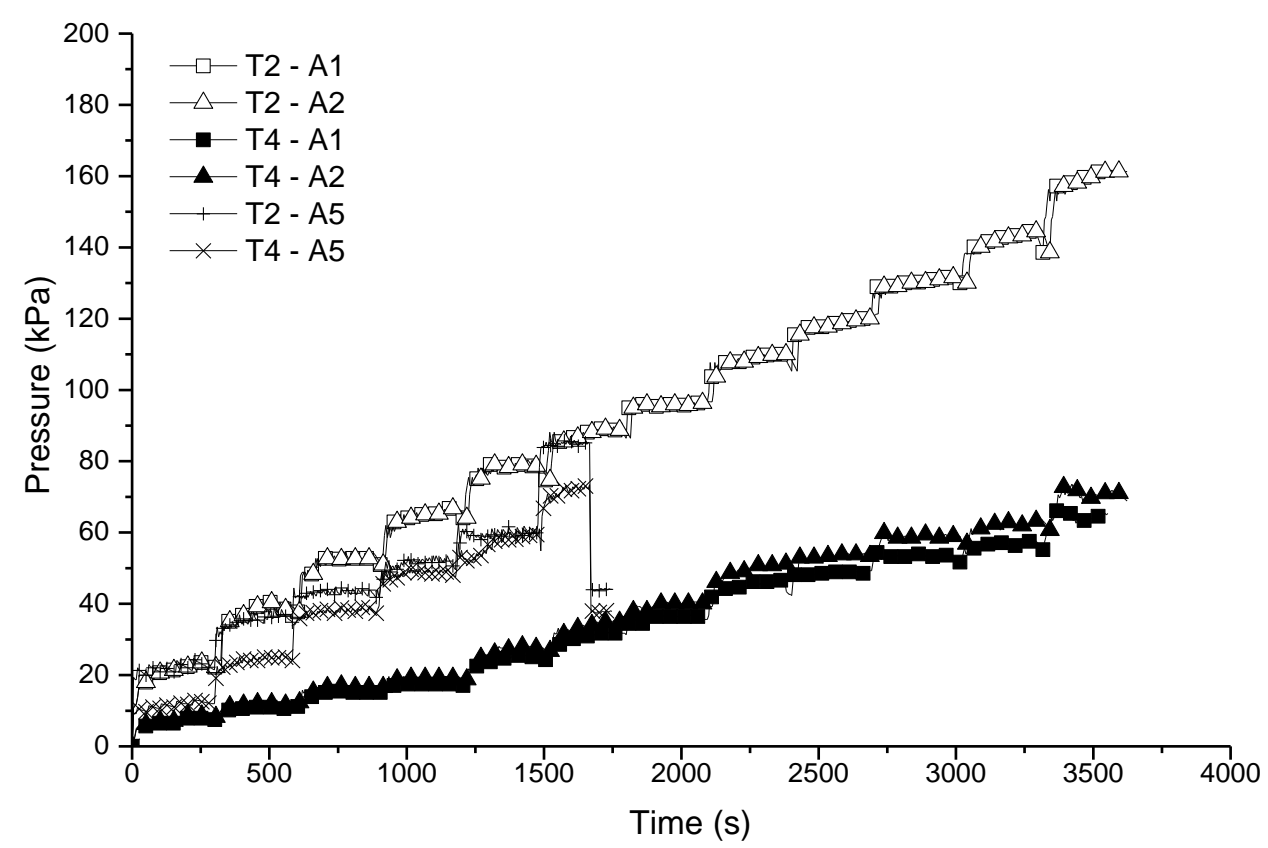

(a) Pressure on T2 and T4 Pressure cells for tests A1, A2 and A5

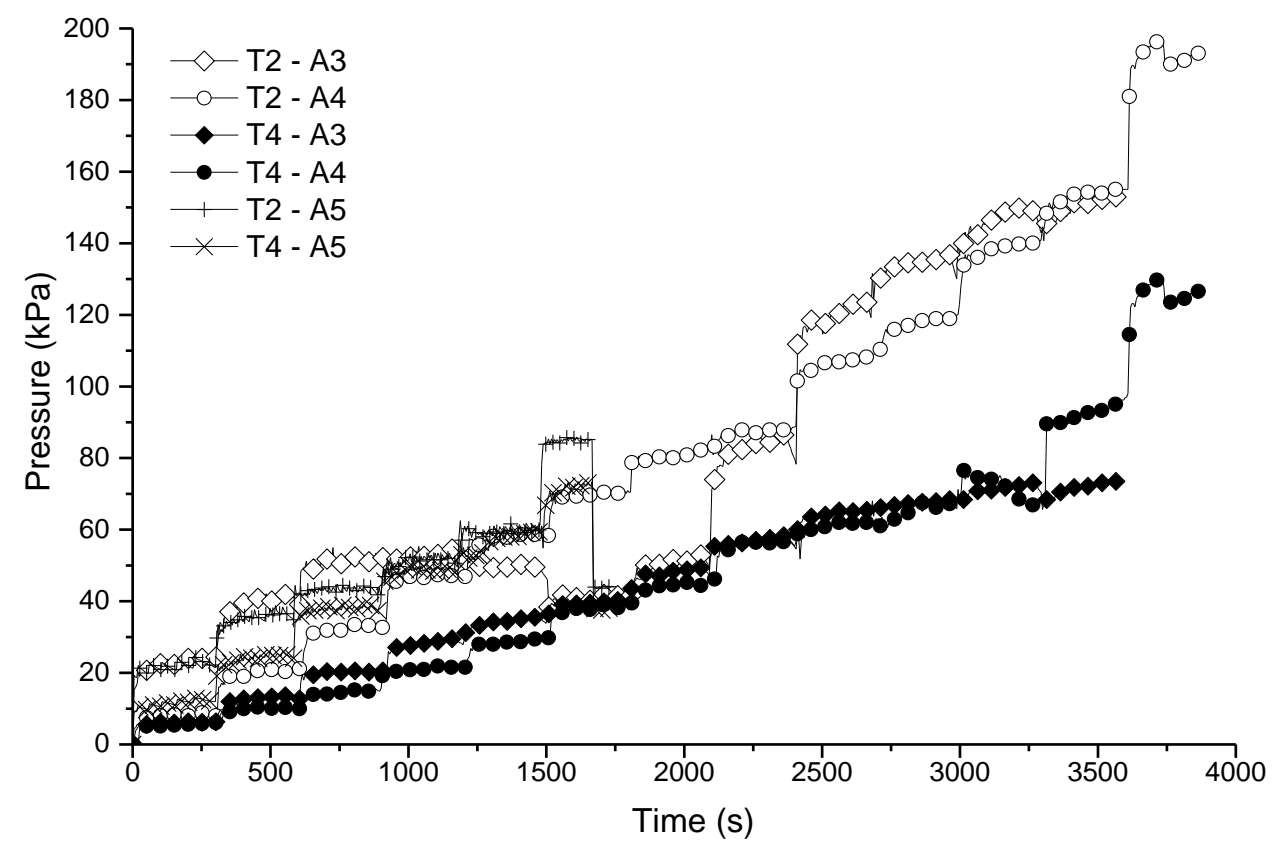

(b) Pressure on T2 and T4 Pressure cells for tests A3, A4 and A5

Figure 3- Pressure cell measurement, readings on T2 and T4 for: a) tests A1, A2 and $\mathrm{A} 5$ and $\mathrm{b})$ tests $\mathrm{A} 3, \mathrm{~A} 4$ and $\mathrm{A} 5$ 


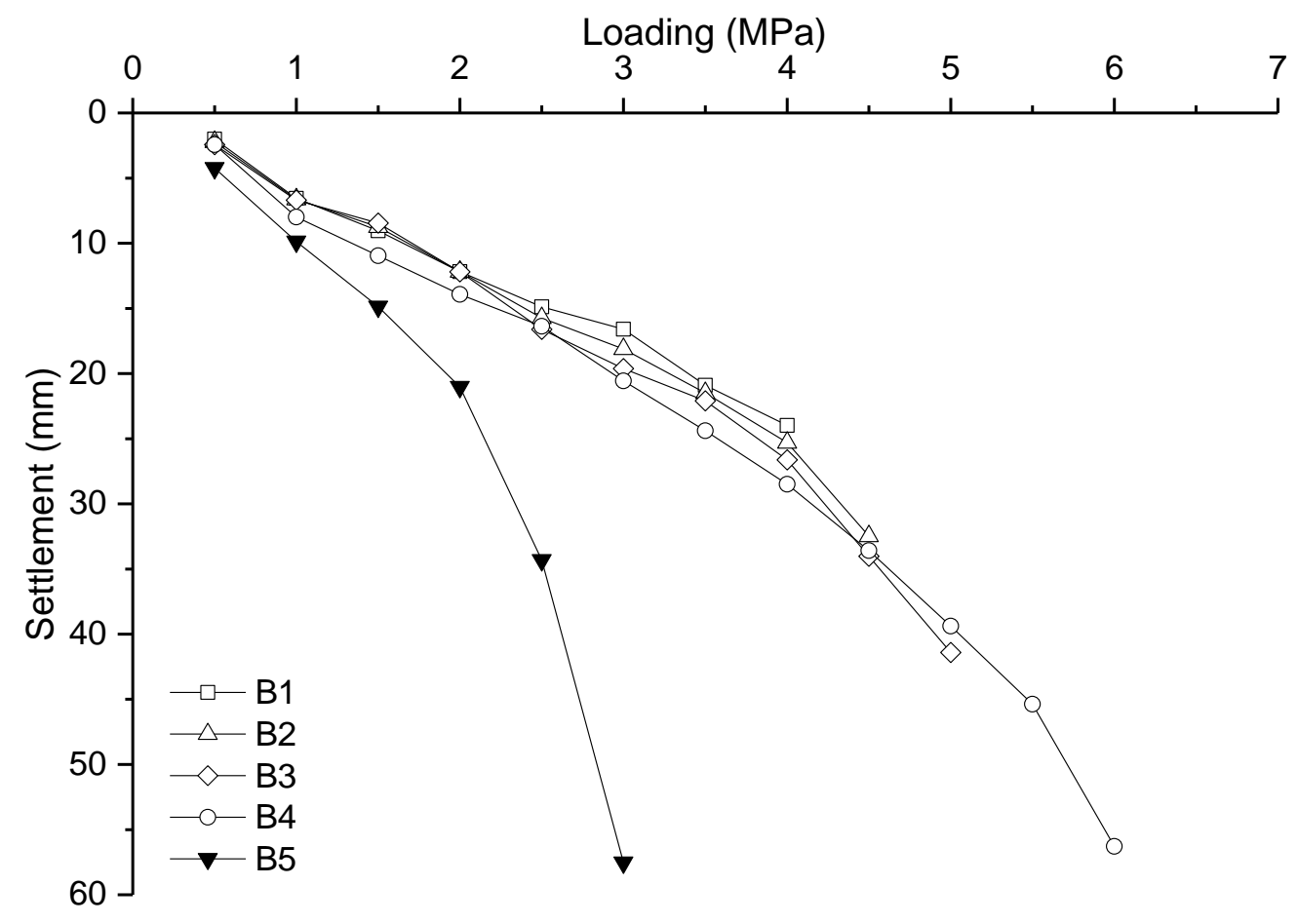

a) Near the central axis

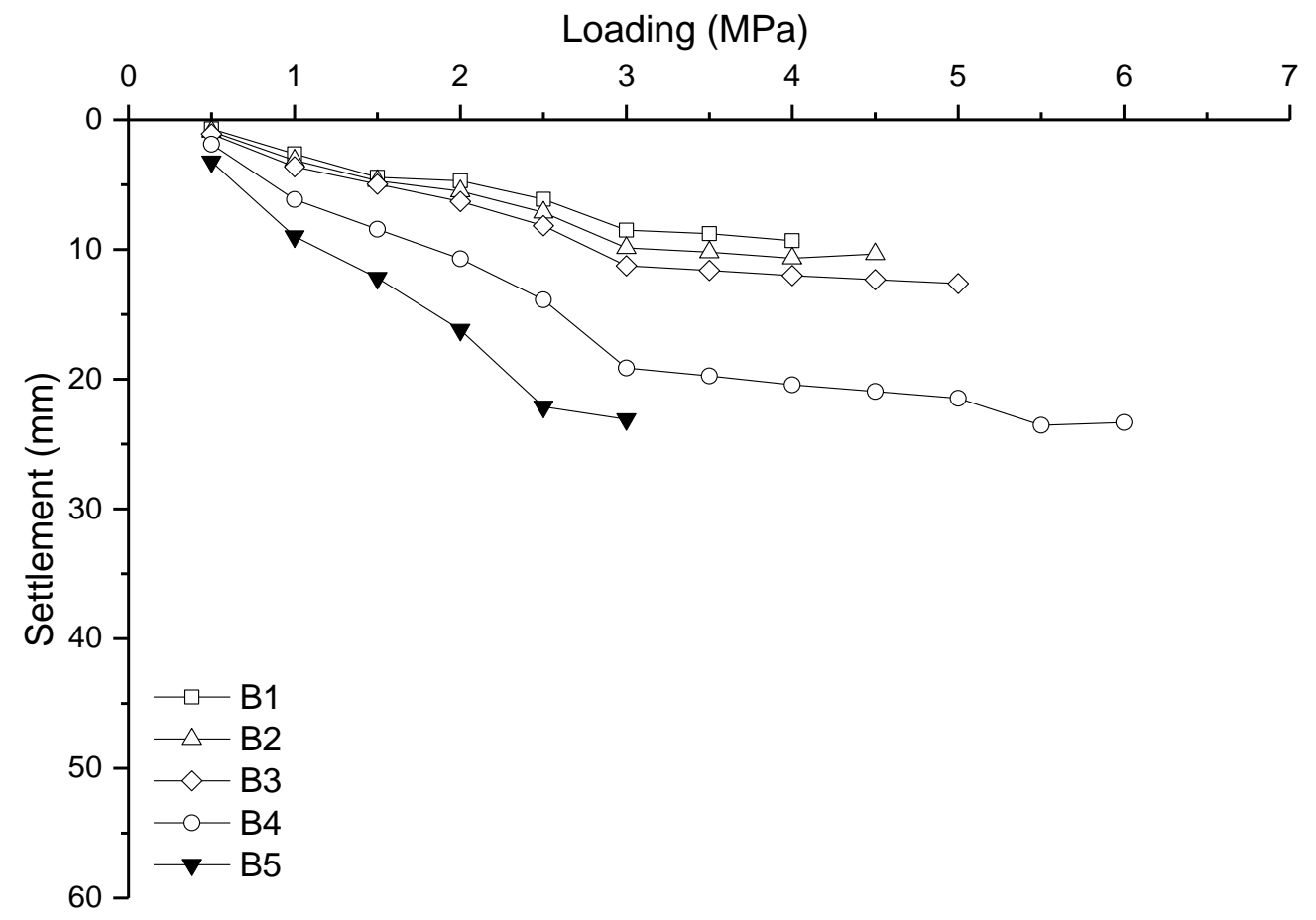

b) Near the slope surface

Figure 4- Settlement-loading curves of the sand embankment with relative density = 32\%: a) near the central axis and b) near the slope surface 


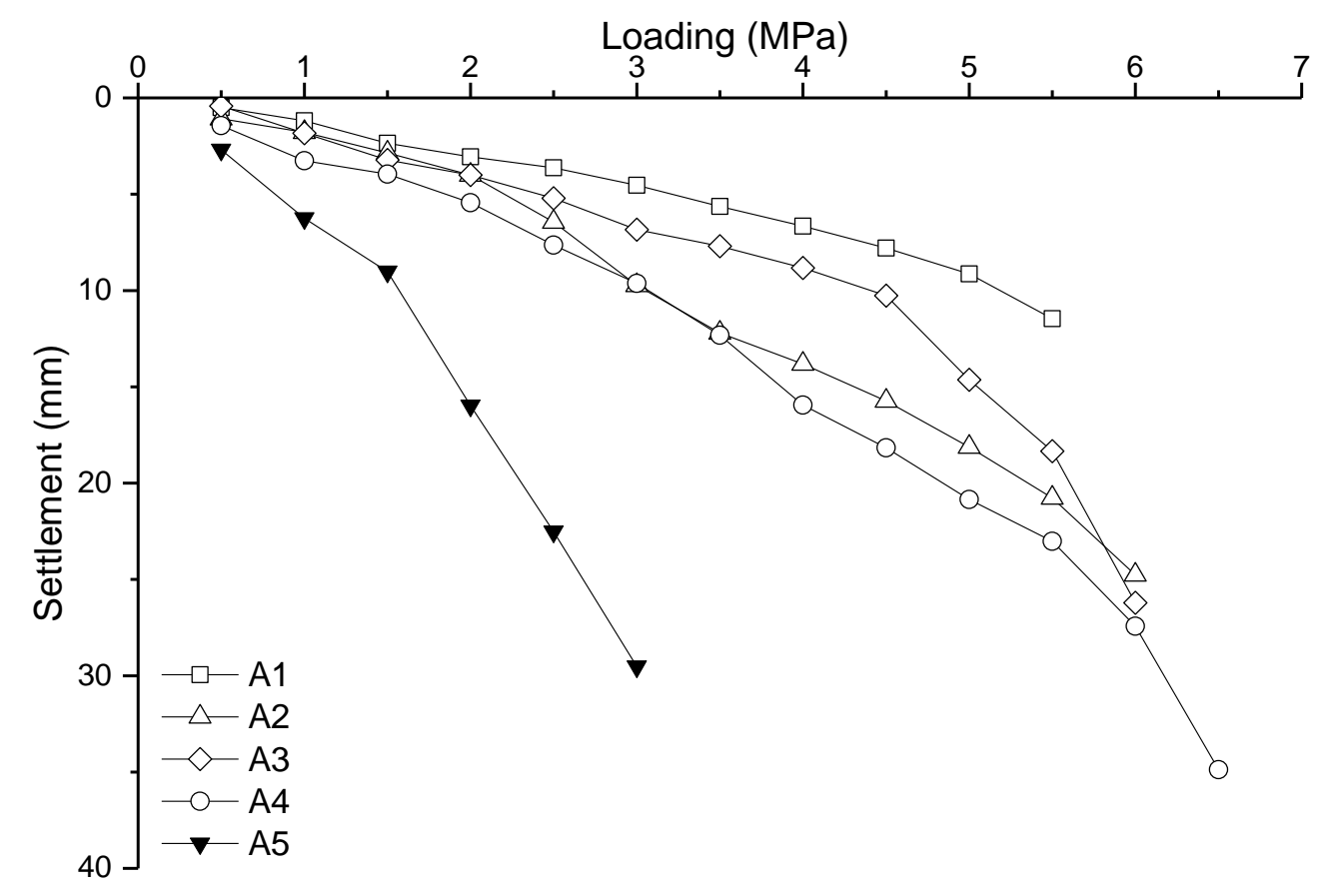

a) Near the central axis

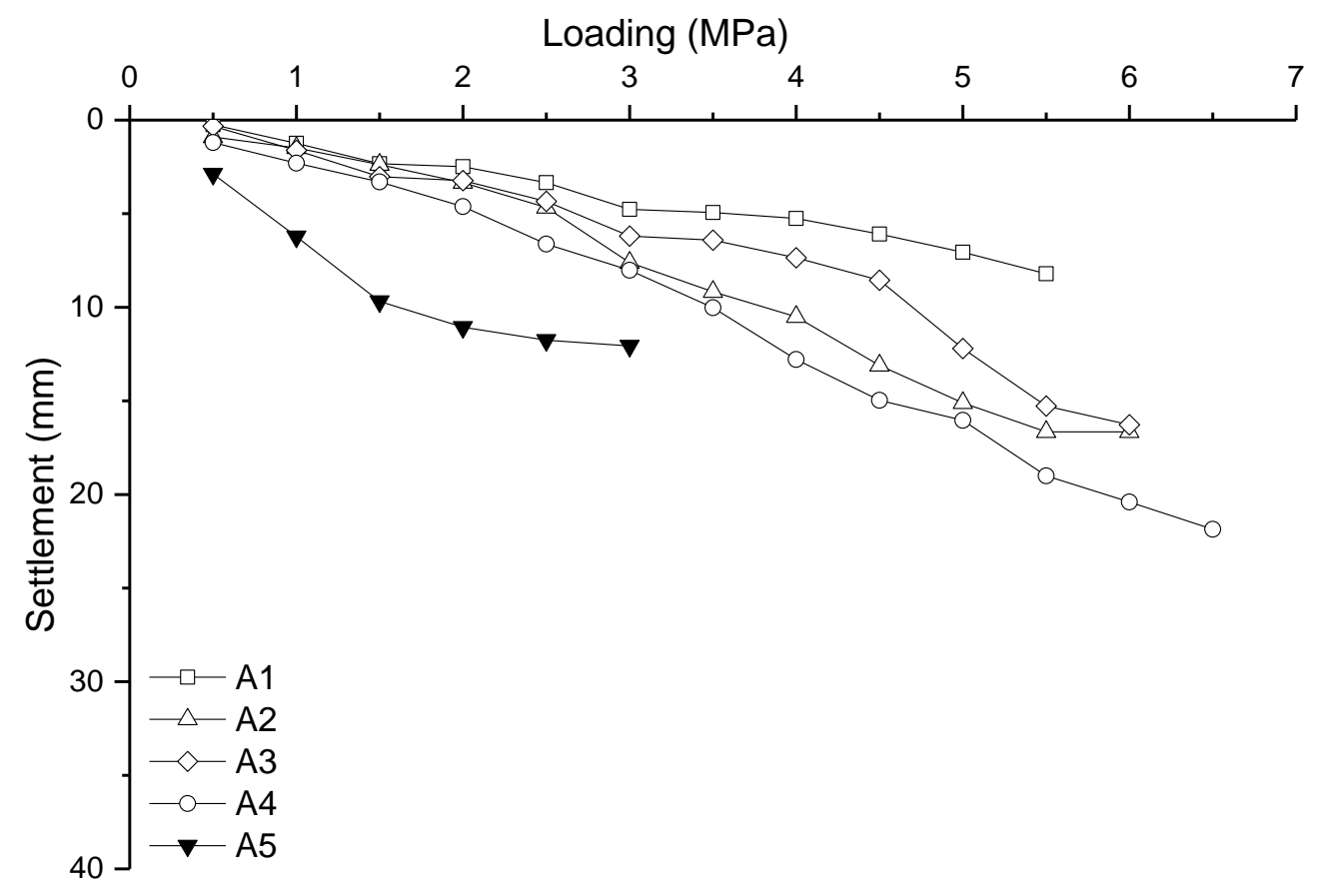

b) Near the slope surface

Figure 5- Settlement-loading curves of the sand embankment with relative density = 45\%: a) near the central axis and b) near the slope surface 


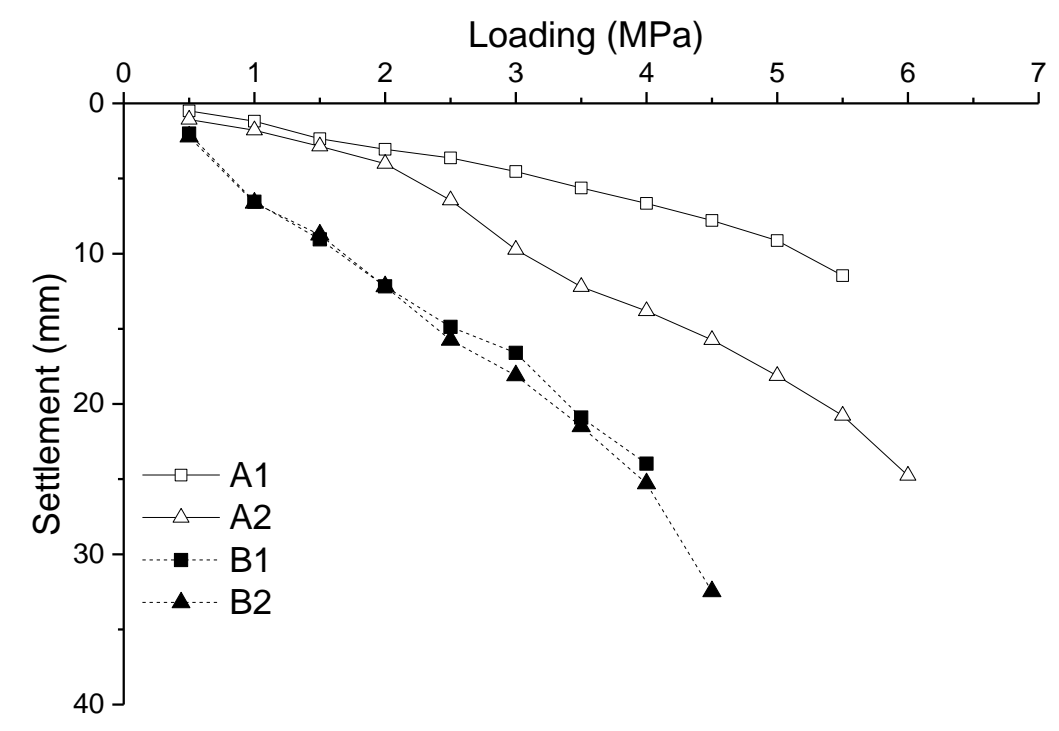

(a) Vertical reinforcing space between layers of $100 \mathrm{~mm}$

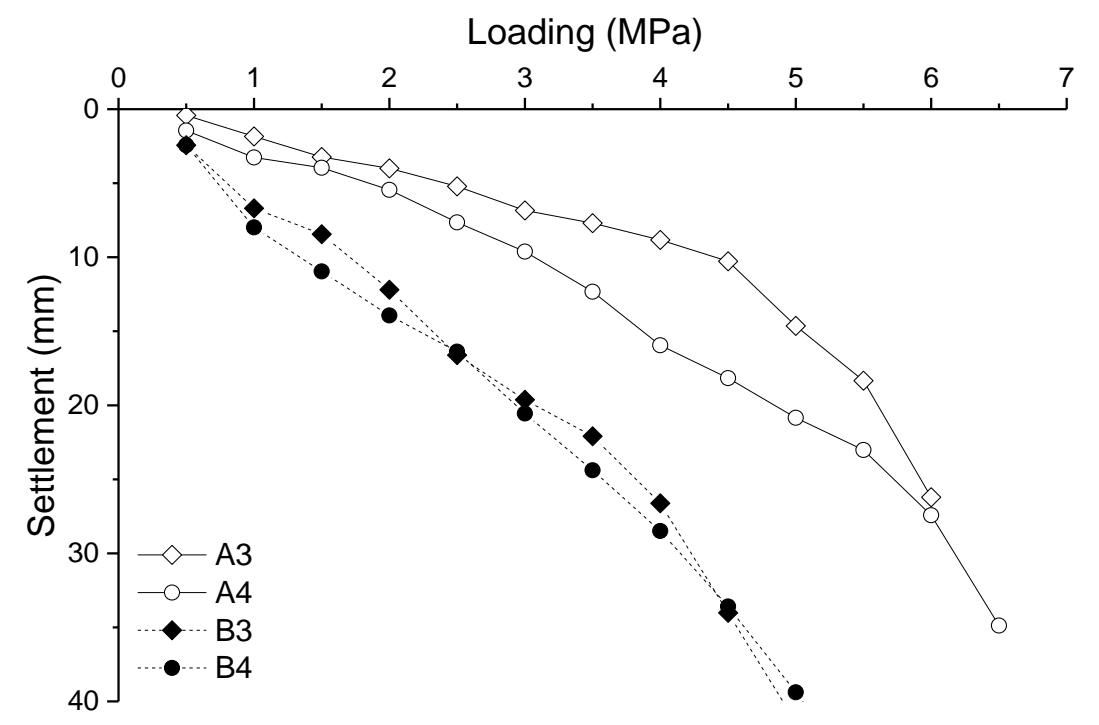

(b) Vertical reinforcement space between layers of $150 \mathrm{~mm}$

Figure 6- Comparison between tests with the same distance separating the tyre reinforcement layers: a) vertical reinforcement space of $100 \mathrm{~mm}$ and b) vertical reinforcement space of $150 \mathrm{~mm}$ 


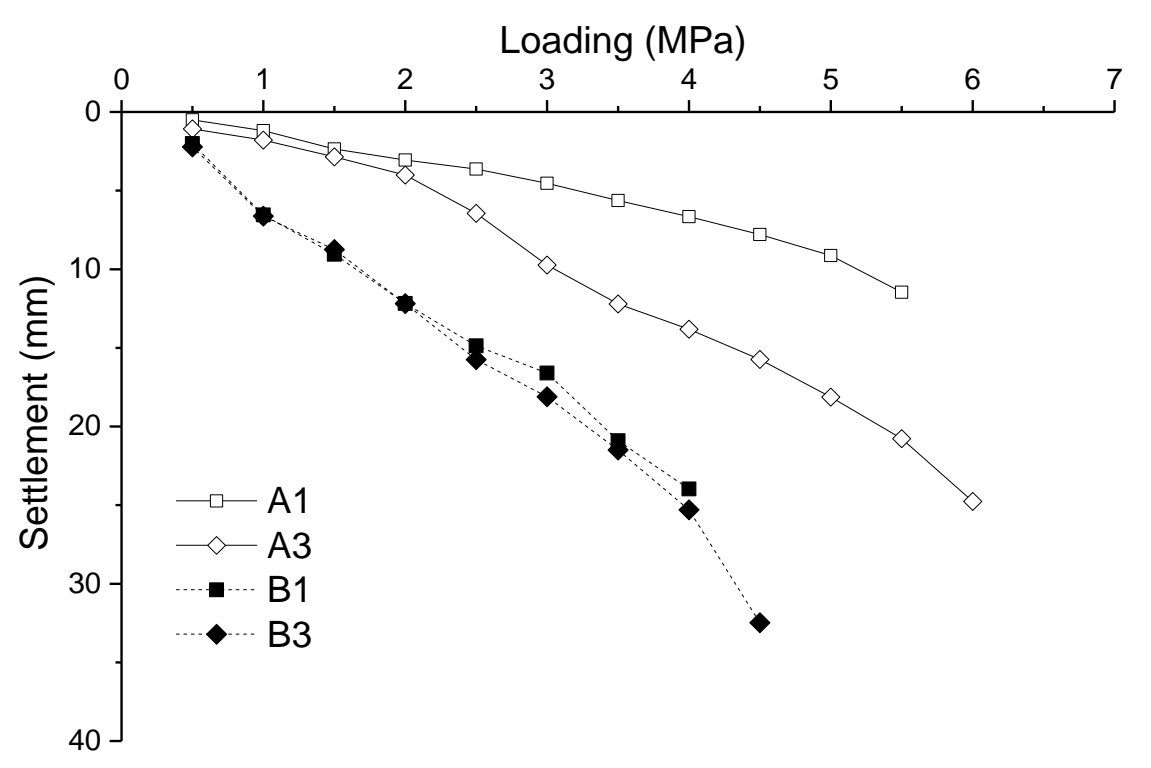

(a) Distance between top tyre layer and loading plate of $250 \mathrm{~mm}$

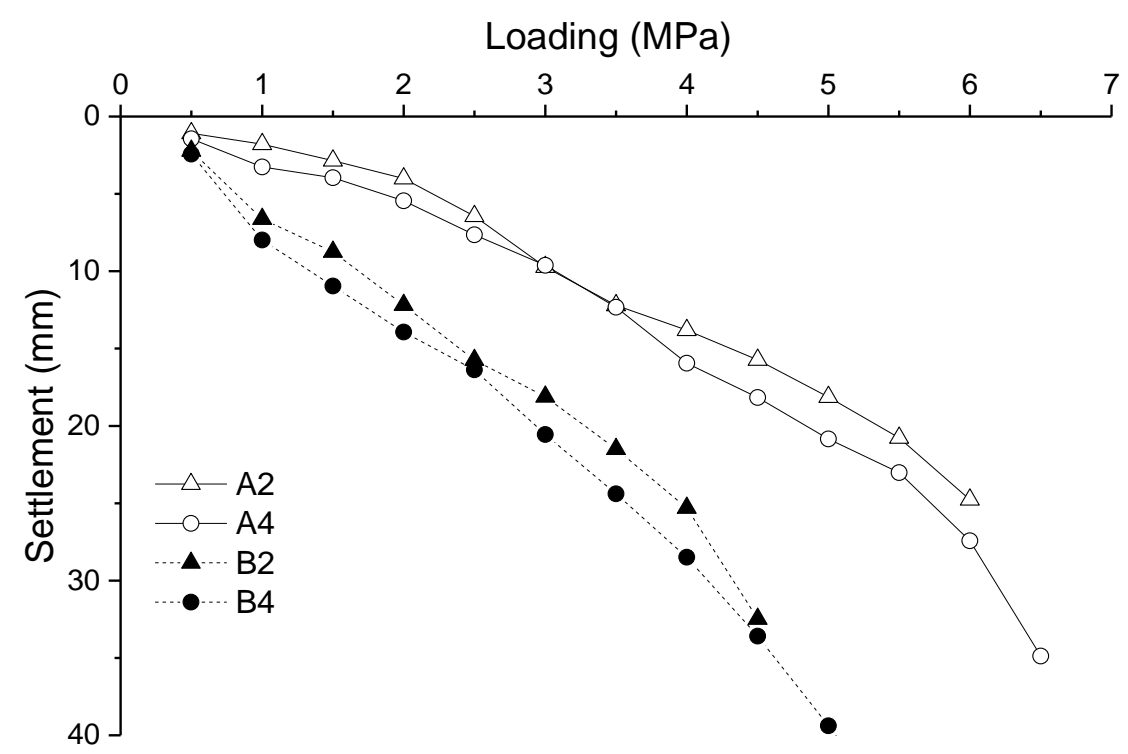

(b) Distance between top tyre layer and loading plate of 300mm

Figure 7- Comparison of the settlement-loading curves for tests with different distances between the top tyre layer and the loading plate: a) distance between the top tyre layer and loading plate of $250 \mathrm{~mm}$ and $\mathrm{b}$ ) distance between the top tyre layer and loading plate of $300 \mathrm{~mm}$. 


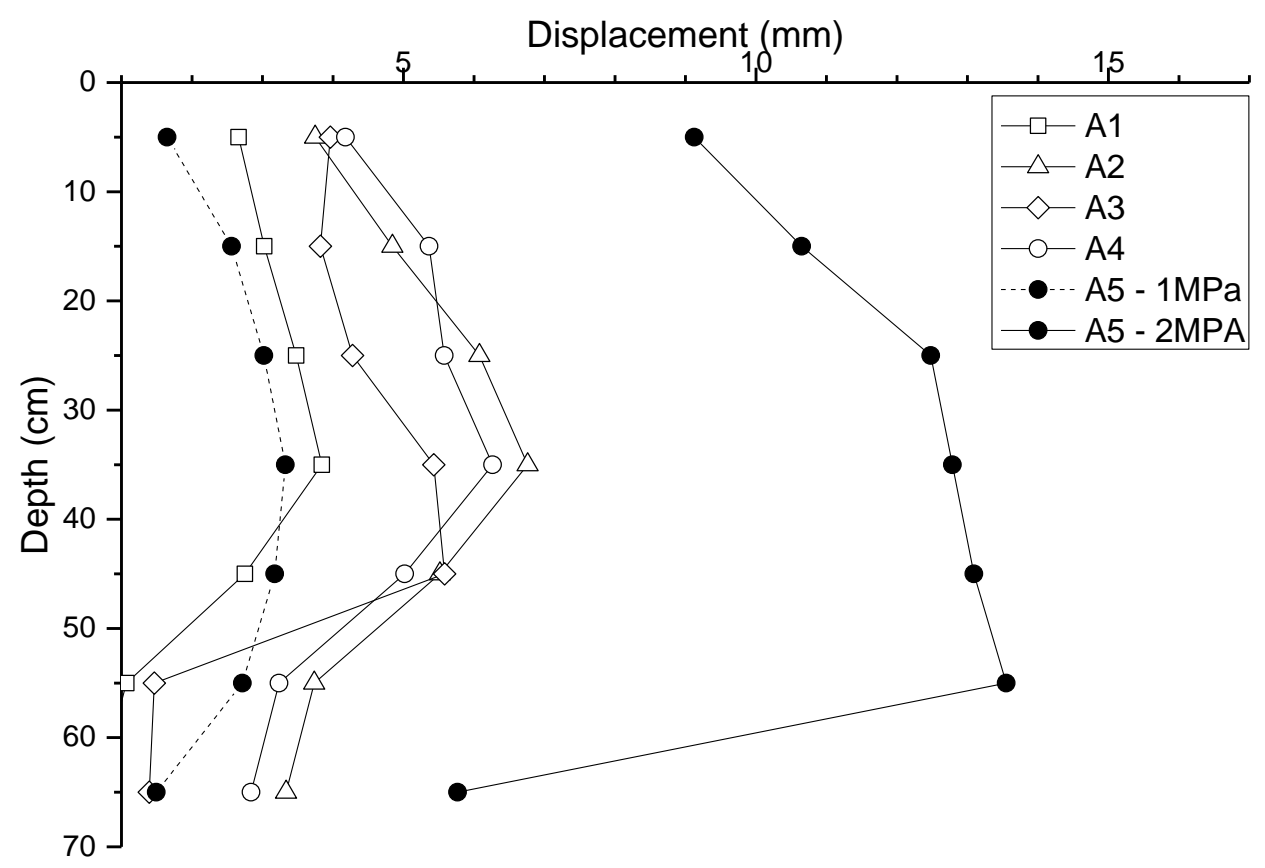

Figure 8 - Horizontal displacement measured on Tests A with a vertical pressure applied on the loading system of $2 \mathrm{MPa}$. 


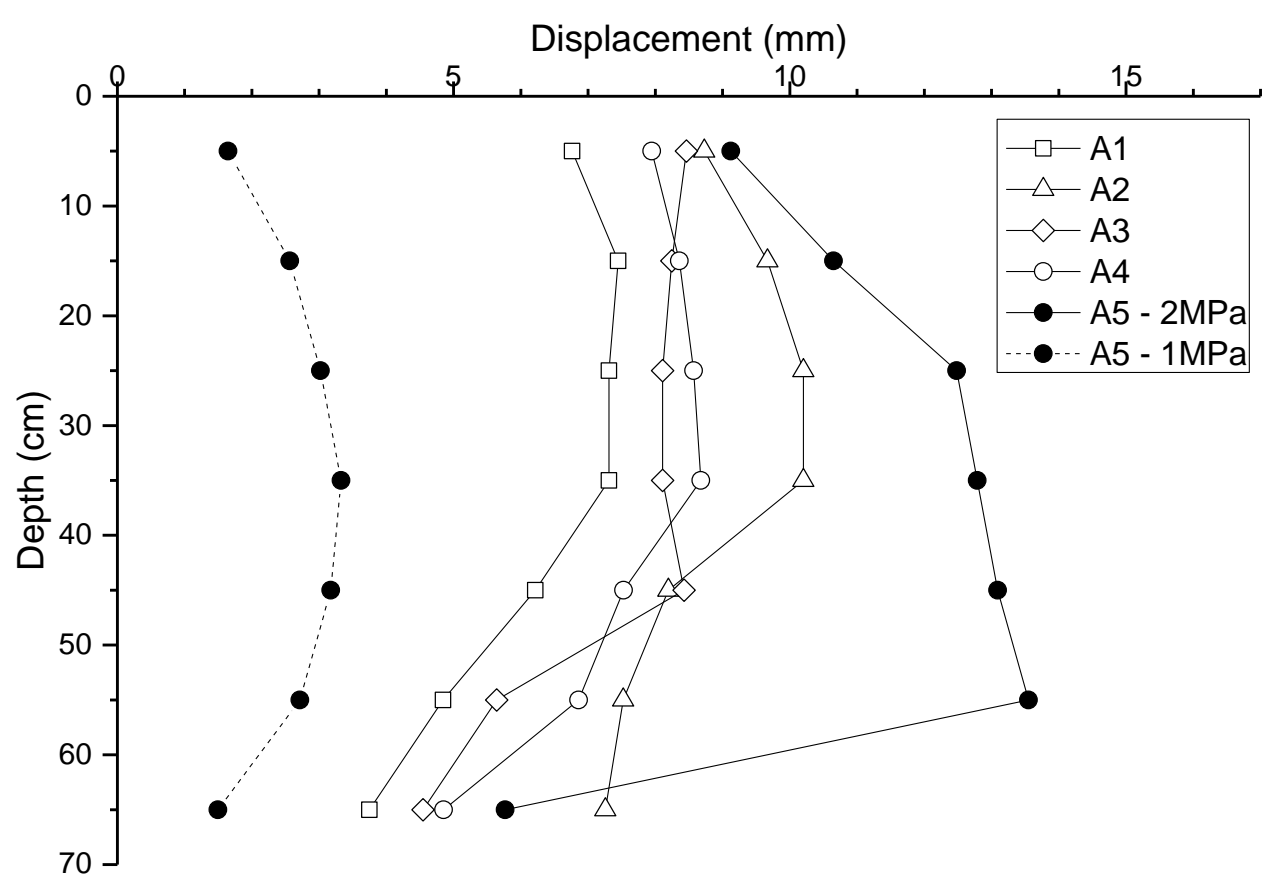

Figure 9 - Horizontal displacement measured on Tests A with a vertical pressure applied on the loading system of $4 \mathrm{MPa}$. 


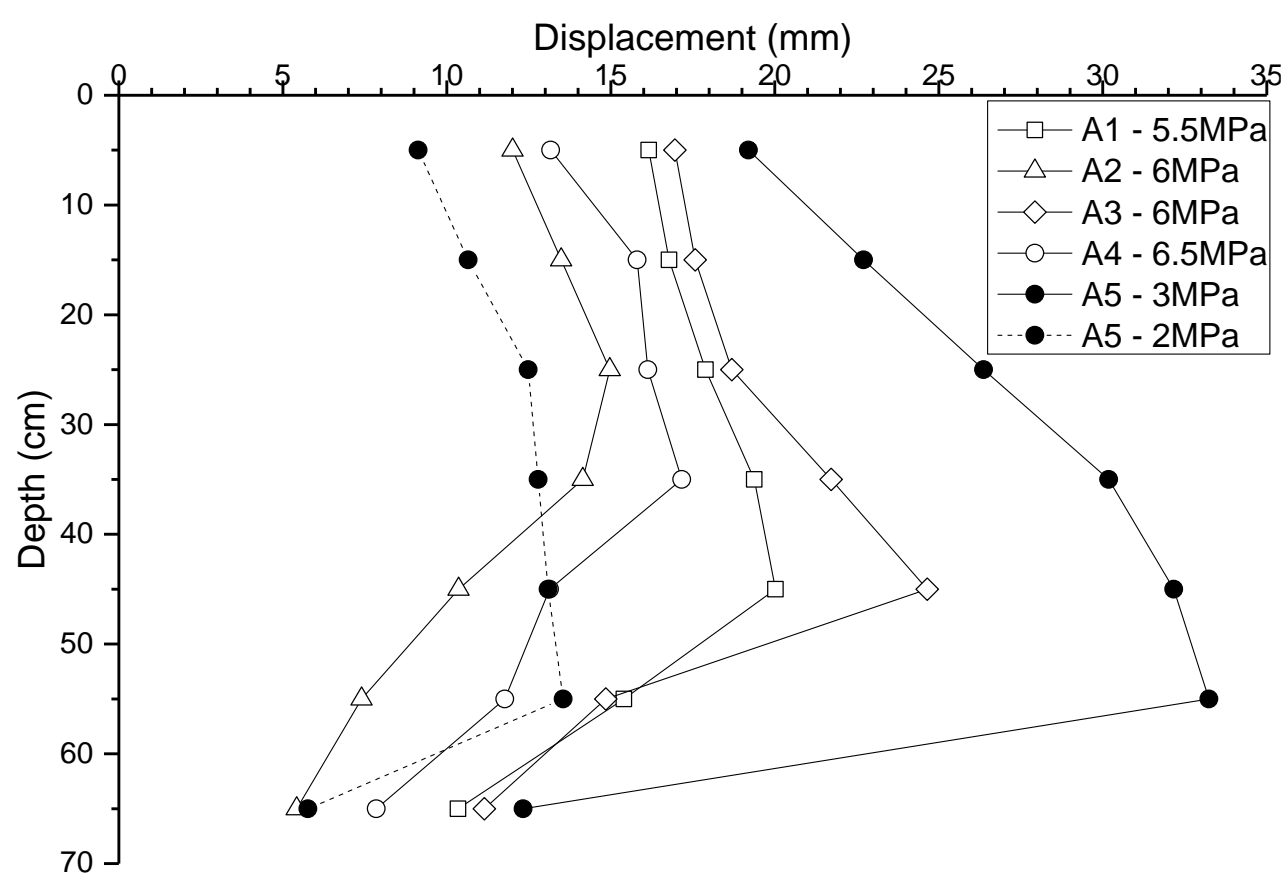

Figure 10 - Horizontal displacement measured on Tests A before failure. Pressure applied on the loading system indicated on each test. 


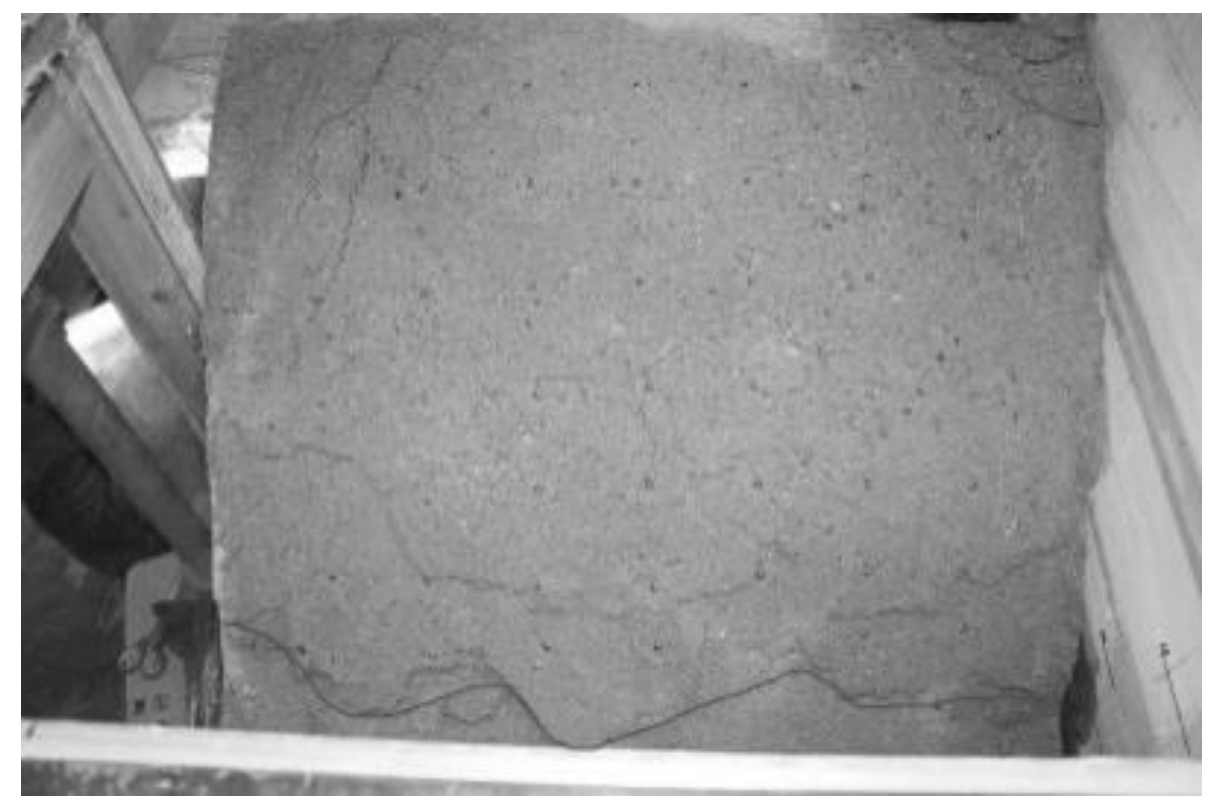

(a) Test A5 (unreinforced)

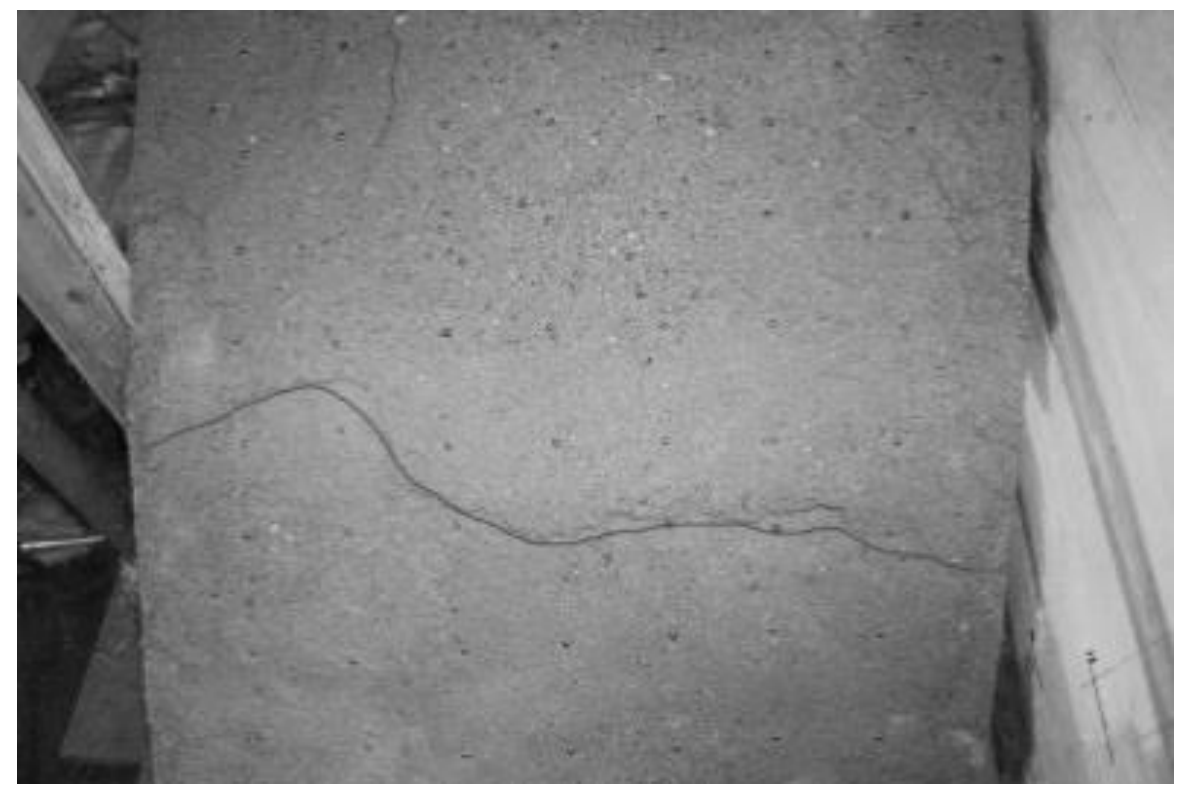

(b) Test A1 


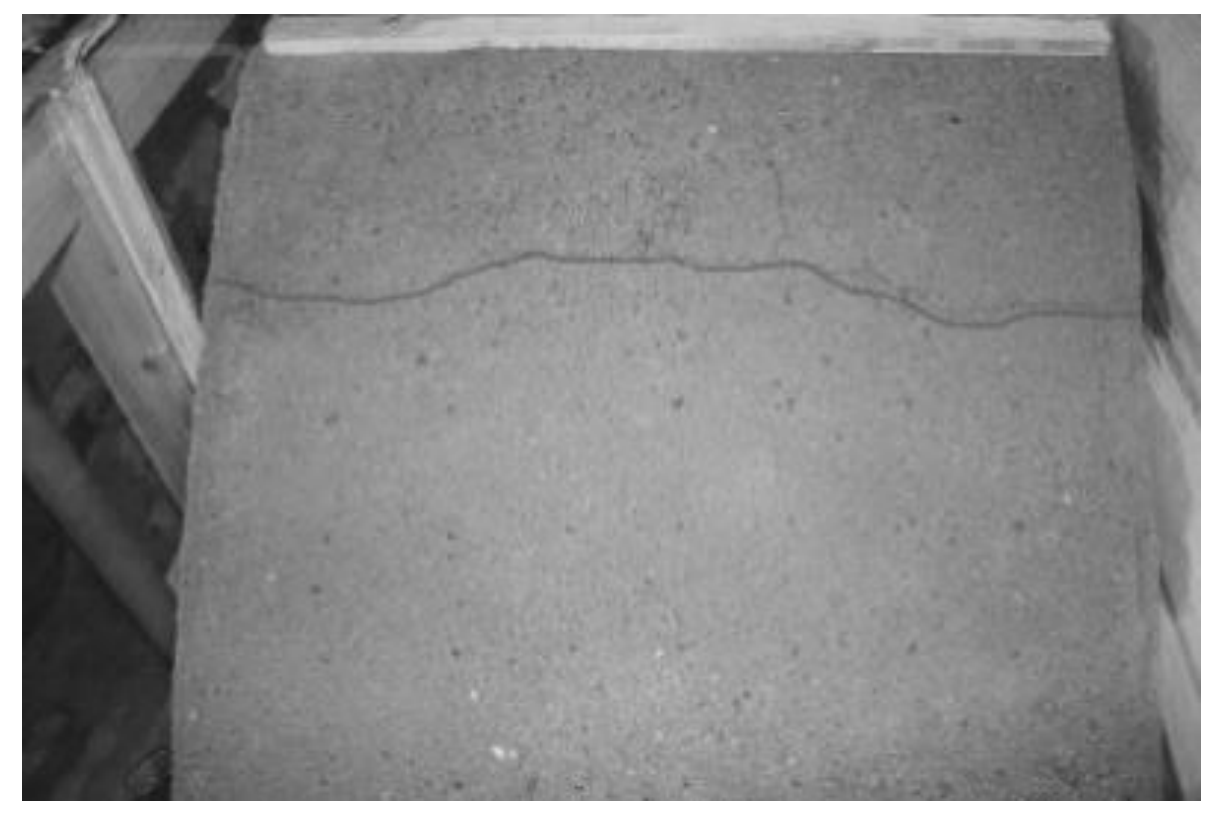

(c) Test A2

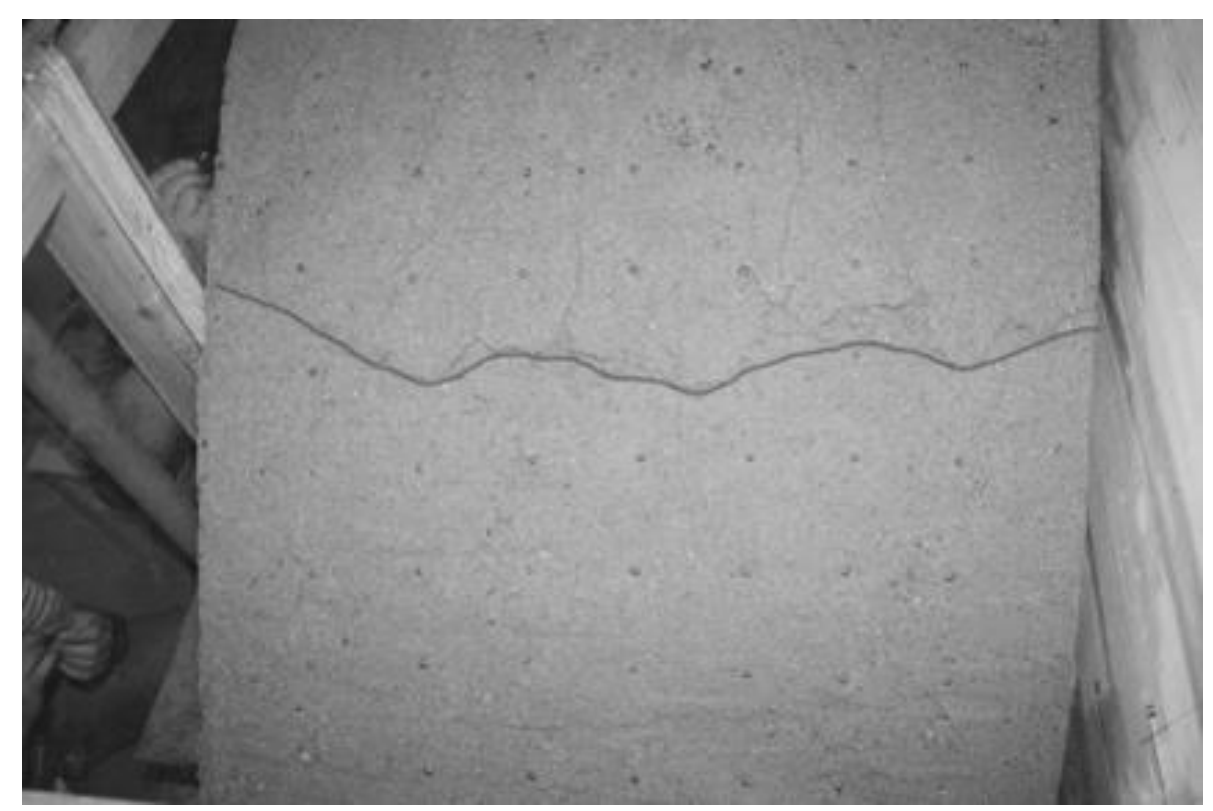

(d) Test A3 


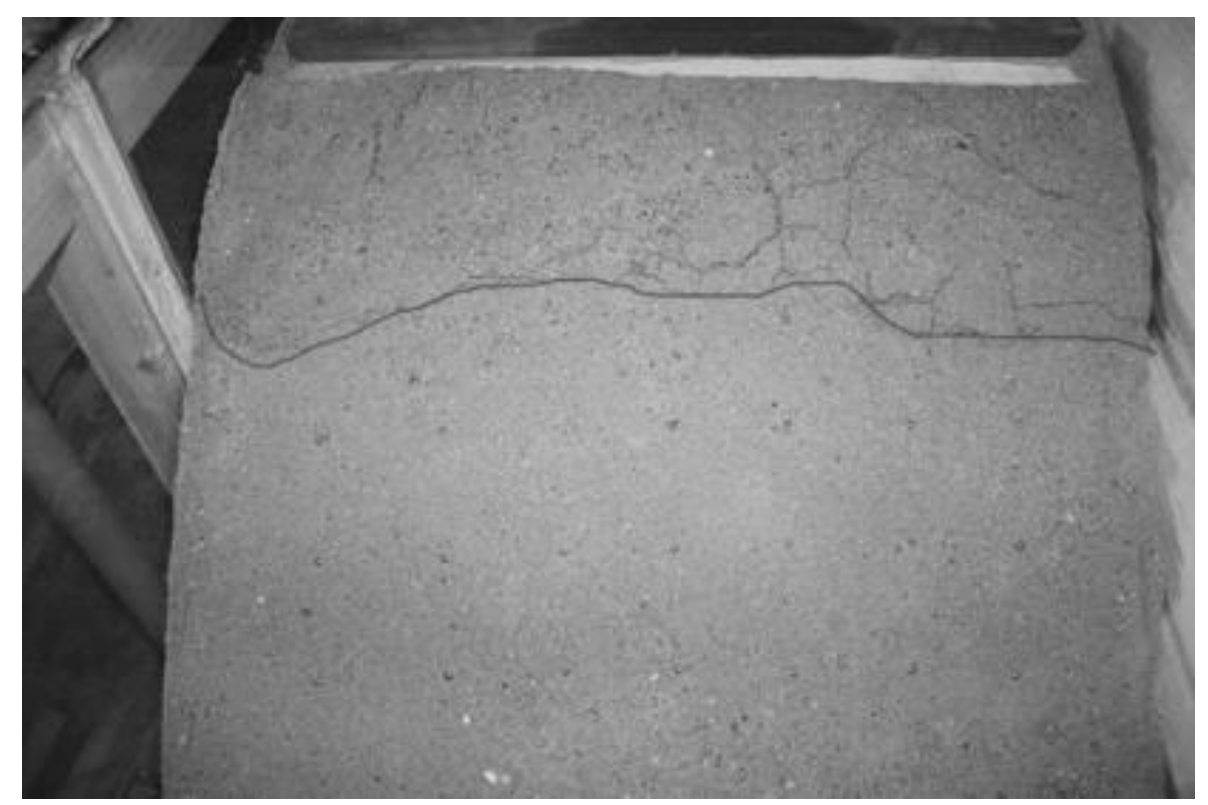

(e) Test A4

Figure 11- Failure mode (the line shows the location of the lowest shear surface on the slope face): a) Test A5; b) Test A1; c) Test A2; d) Test A3 and e) Test A4 